\title{
Frequency of Blastocystis bominis and other intestinal parasites in stool samples examined at the Parasitology Laboratory of the School of Pharmaceutical Sciences at the São Paulo State University, Araraquara
}

\author{
Frequiência de Blastocystis hominis e outros enteroparasitas em amostras \\ de fezes examinadas no Laboratório de Parasitologia da \\ Faculdade de Ciências Farmacêuticas da Universidade Estadual Paulista, Araraquara
}

\author{
Júlio César Miné ${ }^{1}$ and João Aristeu da Rosa ${ }^{1}$
}

\begin{abstract}
Blastocystis homins is a protozoan that causes an intestinal infection known as human blastocystosis. This infection is diagnosed by means of parasitological examination of stools and by permanent staining techniques. The present study was developed to evaluate the frequency of Blastocystis hominis infection among inhabitants of the Araraquara region, State of São Paulo, and to compare different methods for investigating this protozoan in feces samples. Evaluations on 503 stool samples were performed by means of direct fresh examination and using the techniques of Faust et al., Lutz and Rugai et al. In addition, the iron hematoxylin, trichrome and modified Kinyoun staining techniques were used. Out of the 503 samples examined, $174(34.6 \%)$ were found to be positive for the presence of intestinal parasites. The most frequent protozoa and helminths were Entamoeba coli (14.6\%) and Strongyloides stercoralis (6.7\%), respectively. Blastocystis bominis was present in 23 (4.6\%) fecal samples, with a predominately pasty consistency and without characterizing a condition of diarrhea. Despite the low frequency of Blastocystis hominis found in the Araraquara region, compared with other regions of Brazil, it is important to perform laboratory diagnostic tests for this protozoan. Its finding in fecal material is indicative of food and drinking water contamination. Since the transmission route for this parasite is accepted to be oral-fecal, this implies that the population needs guidance regarding hygiene and basic sanitation measures as a means for controlling health problems caused by enteroparasites.
\end{abstract}

Key-words: Blastocystis hominis. Diagnosis. Intestinal parasites. Coproparasitology.

\section{RESUMO}

Blastocystis hominis é um protozoário, causador de infecção intestinal denominada blastocistose humana, cujo diagnóstico é realizado pelo exame coproparasitológico e por meio de técnicas de coloração permanente. Este estudo foi desenvolvido para avaliar a frequiência da infecção por Blastocystis hominis em habitantes da região de Araraquara/SP, bem como comparar diferentes métodos para a pesquisa desse protozoário em amostras de fezes. Foram estudadas 503 amostras de fezes submetidas ao exame direto a fresco, às técnicas de Faust e cols, Lutz e de Rugai e cols, além das colorações pela hematoxilina férrica, tricrômio e de Kinyoun modificada. Entre as 503 amostras examinadas, 174 (34,6\%) apresentaram-se positivas para a presença de parasitas intestinais. 0 protozoário e o helminto mais freqüentes foram Entamoeba coli (14,6\%) e Strongyloides stercoralis (6,7\%), respectivamente. Blastocystis hominis foi observado em 23 (4,6\%) amostras fecais com consistência predominantemente pastosa, não caracterizando quadro diarréico. Apesar da baixa frequiência de Blastocystis hominis encontrada na região de Araraquara, comparativamente a outras regiões brasileiras, é importante a realização do diagnóstico laboratorial desse protozoário. 0 encontro de Blastocystis hominis em material fecal é indicativo de contaminação de alimentos e água de consumo, desde que se admita a rota de transmissão oral-fecal desse parasita, o que implica na orientação da população sobre as medidas de saneamento básico e higiene como meio para se controlar problemas de saúde ocasionados pelos enteroparasitas.

Palavras-chaves: Blastocystis hominis. Diagnóstico. Enteroparasitas. Coproparasitologia.

\footnotetext{
1. Laboratório de Parasitologia, Departamento de Ciências Biológicas, Faculdade de Ciências Farmacêuticas, Universidade Estadual Paulista, Araraquara, SP. Financial support: Conselho Nacional de Desenvolvimento Científico e Tecnológico.

Address to: Dr. Júlio César Miné. Deptº de Ciências Biológicas/FCF/UNESP. Rodovia Araraquara-Jaú, Km 1, Caixa Postal 502, 14801-902 Araraquara, SP. Tel: $55163301-6945$

e-mail: minej@fcfar.unesp.br

Recebido para publicação em 14/12/2007

Aceito em 29/10/2008
} 
Intestinal infections by protozoa and helminths are a recurrent feature in disadvantaged populations living under poor sanitary conditions, although such infections can also occur in communities with a high standard of living and education. The climate, coupled with a lack of information about proper sanitation, favors intestinal parasitosis, which thus represents a severe public health problem in developing countries, where the growth in the population has not been matched by any improvement in sanitation ${ }^{11}$. It is estimated that 3.5 billion people around the world are affected by protozoa and/or helminths and that around 450 million people present parasitic diseases ${ }^{20}$.

The intestinal parasites prevalent among the Brazilian population require laboratory analysis to determine the parasite species. Intestinal parasitosis is usually diagnosed by examination of stool samples, using very simple methods in which the forms of the parasites are observed. However, there are some kinds of protozoan that require special staining techniques for them to be recognized under the microscope $\mathrm{e}^{6}$.

Advances in medical science have made great contributions towards public health, with regard to correct identification of the parasitic agents that cause intestinal infections ${ }^{6}$. Currently, there is growing interest in a subject that is now considered a key topic in parasitology: emergent or opportunist parasites. One example of this class of parasite is Blastocystis bominis, which causes an intestinal infection known as human blastocystosis, for which the symptoms are not specific but include diarrhea, abdominal pain, cramps, nausea, fever, vomiting and flatulence, among other symptoms $^{726}$.

Blastocystis bominis is a polymorphic parasite that presents in vacuolar, granular, multivacuolar, amoeboid, non-vacuolar and cystic forms. Its length ranges from 6 to $40 \mu \mathrm{m}$ and it is detected in feces by means of the usual parasitological laboratory techniques ${ }^{22}{ }^{26}$. It is assumed that human infection by Blastocystis hominis occurs through ingestion of contaminated food or by means of water transportation of the cystic form. It then turns into the vacuolar form in the human intestine. However, the origin of the other forms in which Blastocystis hominis can be found is not yet known ${ }^{23}$.

It is unusual to report the presence of Blastocystis hominis among the results from fecal examination, not only because this parasite is not considered pathogenic, but also because there are few people trained to perform the diagnosis ${ }^{1}$.

Four Blastocystis species have been reported to be parasites of non-human hosts: Blastocystis galli, Blastocystis anatis, Blastocystis anseri and Blastocystis lapem ${ }^{23}$. However, it is not known whether these species can also produce parasitic infections in human beings, since Blastocystis hominis is the only species in the genus that can be found in human feces ${ }^{22}$.

In surveys conducted in several cities in the State of São Paulo (Campinas ${ }^{24}$, Botucatu ${ }^{9}$, Holambra ${ }^{10}$ and the City of São Paulo $^{12}$ ), in Rio de Janeiro ${ }^{15}$ and in Pitanga (State of Paraná) ${ }^{16}$, Blastocystis hominis forms were found in the stool samples examined. Moreover, this parasite may cause parasitic infection in humans (with or without symptoms and whether or not immunosuppression is present), yet diagnostic tests for this parasite are not usually performed in parasitology laboratories.
Therefore, the present study was conducted in order to contribute towards better understanding of the epidemiological features of this parasite. Thus, the frequencies of Blastocystis bominis and other intestinal parasites were evaluated in fecal specimens from inhabitants of the Araraquara region, State of São Paulo, and different methods for detecting this protozoan were compared.

\section{MATERIAL AND METHODS}

A total of 503 stool samples were taken from individuals of both sexes, ranging from one to 90 years of age, who were attended at the Parasitology Laboratory of the School of Pharmaceutical Sciences at the São Paulo State University (UNESP), Araraquara, Brazil, from January to March and September to December, 2004.

The patients came from the towns of Américo Brasiliense, Gavião Peixoto, Motuca, Rincão and Araraquara.

The project for the work described here (protocol \#27/2003) was approved by the School's Research Ethics Committee, and all the individuals who took part in the research signed an authorization form, giving their written informed consent.

For the parasitological diagnostic tests, one fecal sample from each volunteer was collected in plastic disposable flasks without preservatives, individually identified with the name and age of the volunteer. Additional information about the volunteers' state of health was obtained from interviews with them.

For the laboratory diagnosis of Blastocystis hominis and other intestinal parasites, the stool samples were analyzed by means of direct examination, the zinc sulfate flotation method, spontaneous sedimentation and Rugai's method ${ }^{19}$. Some fecal smears were fixed with Schaudinn's liquid and stained using iron hematoxylin and trichrome. To detect intestinal coccidia, the modified formalinethyl acetate concentration technique was performed, followed by staining using the modified Kinyoun method ${ }^{612}$.

The rate of positive findings was expressed as a percentage, and the statistical analysis was carried out using Fisher's exact test. A probability value of less than 0.05 was considered statistically significant.

\section{RESULTS}

Out of the 503 samples examined, 325 were from females and 178 were from males. Overall, 174 (34.6\%) samples tested positive for intestinal parasitosis and 329 (65.4\%) tested negative. Among the positive cases, 145 were infected by only one parasite, while two or more parasites were detected in 29 individuals. The consistency of the feces was noted, and it was found that, out of the 503 samples brought to the laboratory, $50(9.9 \%)$ of them were diarrheic, 267 (53.1\%) were soft and 186 (37\%) were hard.

Among the 503 samples, 68 (13.5\%) were from patients from Américo Brasiliense and 44 of these were from the local hospital. Most of the samples (194 or 38.6\%) were brought by patients who live in Araraquara. The samples that came from the towns of Gavião 
Peixoto and Motuca - respectively 32 (6.4\%) and 27 (5.4\%) were brought in at scattered intervals, since the occurrences were infrequent. In the case of Rincão, the laboratory was approached by the health department, and 182 (36.2\%) samples were obtained from patients living in a landless community encampment and from a daycare center downtown.

The most frequent protozoan found was Entamoeba coli, followed by Giardia duodenalis and Blastocystis hominis. Among the helminths, the most frequent was Strongyloides stercoralis, followed by hookworms, Trichuris trichiura and Ascaris lumbricoides (Table 1).

Table 2 shows that there was no statistically difference between gender and age of patients with Blastocystis hominis $(\mathrm{p}>0.05)$.

Out of the 23 (4.6\%) samples that were positive for Blastocystis hominis, 15 were collected from female patients and eight from male patients. All these samples were diagnosed positive by means of direct examination with saline solution and were confirmed by fecal smears stained with iron hematoxylin and trichrome staining, while only three samples tested positive for Blastocystis bominis when spontaneous sedimentation and flotation in zinc sulfate were used (Table 3).

Table 1 - Frequency of intestinal parasites among inbabitants of the Araraquara region, State of São Paulo ( $\left.n^{o}=503\right), 2005$.

\begin{tabular}{lcr}
\hline & \multicolumn{2}{c}{ Positive samples } \\
\cline { 2 - 3 } Parasites & $\mathrm{n}^{0}$ & $\%$ \\
\hline Protozoa & & \\
Entamoeba coli & 72 & 14.3 \\
Giardia duodenalis & 33 & 6.7 \\
Blastocystis hominis & 23 & 4.6 \\
Endolimax nana & 5 & 1.0 \\
Iodamoeba butschilii & 4 & 0.8 \\
Chilomastix mesnili & 1 & 0.2 \\
Entamoeba hartmanii & 1 & 0.2 \\
Isospora belli & 1 & 0.2 \\
Helminths & & \\
Strongyloides stercoralis & 33 & 6.7 \\
Hookworms & 8 & 1.6 \\
Trichuris trichiura & 7 & 1.4 \\
Ascaris lumbricoides & 5 & 1.0 \\
Hymenolepis nana & 4 & 0.8 \\
Enterobius vermicularis & 2 & 0.4 \\
Schistosoma mansoni & 1 & 0.2 \\
\hline
\end{tabular}

All the samples that tested positive for Blastocystis hominis presented few specimens of this protozoan, with a total of only five per microscope field.

Most of the cases of Blastocystis hominis infection diagnosed (13 occurrences) were found in individuals between one and 44 years old; in children aged one to 14 years, there were seven occurrences; and only three cases were reported among adults over 45 years old.

Among the samples that came from Araraquara, 18 tested positive for Blastocystis hominis. The samples from Rincão

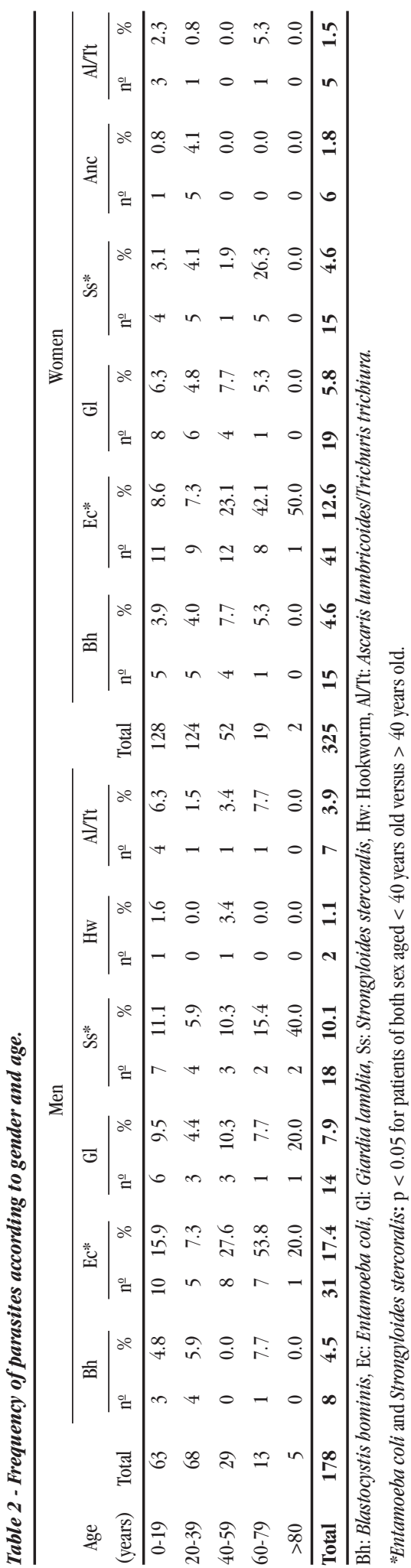

Table 3 - Comparison of the techniques used to diagnose the presence of Blastocystis hominis in stool samples among inhabitants of the Araraquara region, State of São Paulo.

\begin{tabular}{|c|c|c|c|c|c|c|c|c|c|}
\hline \multicolumn{10}{|c|}{ Positive samples $\left(\mathrm{n}^{0}=23\right)$} \\
\hline \multicolumn{2}{|c|}{$\begin{array}{c}\text { Direct } \\
\text { examination* }\end{array}$} & \multicolumn{2}{|c|}{$\begin{array}{l}\text { Zinc sulfate } \\
\text { flotation* }\end{array}$} & \multicolumn{2}{|c|}{$\begin{array}{l}\text { Spontaneous } \\
\text { sedimentation* }\end{array}$} & \multicolumn{2}{|c|}{$\begin{array}{c}\text { Iron } \\
\text { hematoxylin }{ }^{* * *}\end{array}$} & \multicolumn{2}{|c|}{$\begin{array}{l}\text { Trichrome } \\
\text { staining*** }\end{array}$} \\
\hline $\mathrm{n}^{\underline{0}}$ & $\%$ & $\mathrm{n}^{0}$ & $\%$ & $\mathrm{n}^{0}$ & $\%$ & $\mathrm{n}^{0}$ & $\%$ & $\mathrm{n}^{0}$ & $\%$ \\
\hline 23 & 100.0 & 3 & 13.4 & 3 & 13.4 & 23 & 100.0 & 23 & 100.0 \\
\hline
\end{tabular}

* fecal sample without preservatives.** fecal sample preserved with Schaudinn's liquid. 
presented only three positive findings of blastocystosis, while two cases were reported from Américo Brasiliense.

There were no complaints of symptoms among the patients who tested positive for Blastocystis hominis in their feces. Only two of them presented diarrheic feces, and other parasites were found in those stools (Blastocystis hominis + Giardia duodenalis and Blastocystis hominis + Strongyloides stercoralis), but there was a predominance of soft consistency in the stool samples that contained specimens of Blastocystis hominis.

\section{DISCUSSION}

Intestinal parasitosis is very important in our society, since it constitutes a serious public health problem. It is more visible in developing countries in which severe economic, social and sanitary problems are found. These parasitic diseases are important because of the total mortality rates and because of the frequency with which they cause nutritional deficits. These constitute one of the major drains on the strength of the population affected by these diseases. These infections are frequently associated with chronic diarrhea and malnutrition, which compromise physical and intellectual development, especially among young people ${ }^{17}$.

Within this context, we intended in the present study to determine, with the aid of parasitological stool tests, whether Blastocystis hominis was present in the region surrounding and including Araraquara, State of São Paulo, as well as to evaluate the presence of other intestinal parasites.

In the fecal examinations performed in this region, a high prevalence of enteroparasites was discovered in the samples. Evaluation of the results for 1,043 fecal samples from patients who came to this laboratory between 1999 and 2003 revealed that $28.1 \%$ of the individuals presented some kind of parasite. Ascaris lumbricoides, hookworms, Trichuris trichiura and Strongyloides stercoralis were the most prevalent helminths and Giardia duodenalis and Entamoeba coli were the most prevalent protozoa found ${ }^{14}$. In a survey performed during the 1970s, it was shown that the same intestinal parasites were already frequent in this region ${ }^{8}$.

In the present study, it was observed that $36.4 \%$ of the stool samples tested positive for the presence of intestinal parasites. Among the most prevalent of these parasites were the protozoa Entamoeba coli and Giardia duodenalis and the nematodes Strongyloides stercoralis, Trichuris trichiura, hookworms and Ascaris lumbricoides (Table 1).

The large quantity of intestinal parasites detected in this study is rather alarming because Araraquara, where the majority of the tested samples were obtained, has installed a sewage treatment plant that provides almost $100 \%$ coverage for the city's homes ${ }^{4}$. One possible problem is that the hygiene education in this region may be inefficient, considering that the numbers of parasites found have remained constant for the last 30 years ${ }^{814}$.

Only a single fecal sample showed cystic forms of Entamoeba bartmanii, for which the diagnosis was confirmed by iron hematoxylin and trichrome staining and by cystic micrometry.
Interestingly, Cryptosporidium sp oocysts were not observed in all the samples analyzed. This might be explained by single sample analyses instead of multiple analyses, or the absence of preservative liquid in all the samples collected.

One fecal sample was positive for Schistosoma mansoni eggs, thus indicating that this parasite was present in the Araraquara region. This result was notified to the Special Health Service of Araraquara, in order to provide medical healthcare.

Strongyloides stercoralis was observed in 33 (6.7\%) samples by means of Rugai's method. This frequency is equivalent to hyperendemic regions and is compatible with previous findings conducted in the same region ${ }^{31318}$. The frequency of Strongyloides stercoralis infection among patients aged less than 40 years old was significantly higher than it was among patients over 40 years old $(\mathrm{P}<0.05)$ (Table 2$)$. It can therefore be seen that Rugai's method needs to be included in parasitological stool tests.

Among the 23 specimens that tested positive for contamination by Blastocystis hominis, there was no clear difference between the number of men and women parasitized by this protozoan (Table 2), which is concordant with the findings from other authors ${ }^{25}$.

Studies during the 1990s showed that the prevalence of Blastocystis hominis in developed countries ranges from 1.5 to $10 \%$, while in developing countries the rate rises to 30 to $50 \%{ }^{721}$. The data on the prevalence of this protozoan in Brazil generally coincide with the observations of authors in other developing countries, although there are some studies that show results similar to those found in the more developed countries.

Regarding the consistency of the feces that tested positive for Blastocystis hominis, only two of the samples were diarrheic while 21 were soft or hard, thus resembling the data found in a study carried out at the teaching hospital of the School of Medicine at the University of São Paulo5.

The quality of the drinking water in the Araraquara region is very good, compared with other regions of the state and beyond, in other parts of the country ${ }^{6}$. This may be a determining factor for the low frequency of Blastocystis bominis found in the present study, considering that the transmission of this protozoan is oralfecal and that it can be spread by water ${ }^{23}$.

In this study, fresh direct examination of stool material was found to be the best method for diagnosing Blastocystis hominis, as previously reported in $2003^{1}$. On the other hand, staining with iron hematoxylin and trichrome proved to be as efficient as direct examination for confirming the presence of this protozoan in the feces. Spontaneous sedimentation and flotation in zinc sulfate were inefficient methods because the fecal samples were not preserved (Table 3).

Blastocystis hominis was found in 23 (4.3\%) of the 503 stool samples that were examined. This observation was unheard of in the region under study, where the clinical analysis laboratories do not include such findings on the report sheet that is given to the patient. This practice may be because the laboratory personnel are unfamiliar with and disregard this protozoan, or because it is present as a commensal ${ }^{2}$. Thus, there is a need to include protozoa such as Entamoeba coli, Endolimax nana, Chilomastix mesnili and Iodamoeba bütschlii on laboratory reports sheets. 


\section{ACKNOWLEDGEMENTS}

To the volunteers of this study; to Dr Vera Lucy de Santi Alvarenga, Dr Isabel Martinez and Ms Maria Zenaide Tita Fernandes for technical assistance; to Dr Mara Cristina Pinto and Dr Márcia Graminha for critical reading of the manuscript and Ms Cláudia Solano Rocha for advice on statistical analysis.

\section{REFERENCES}

1. Amato Neto V, Alarcón RSR, Gakiya E, Bezerra RC, Ferreira CS, Braz LMA. Blastocistose: controvérsias e indefinições. Revista da Sociedade Brasileira de Medicina Tropical 36:515-517, 2003.

2. Amato Neto V, Alarcón RSR, Gakiya E, Ferreira CS, Bezerra RC, Santos AG. Elevada Porcentagem de blastocistose em escolares de São Paulo, SP. Revista da Sociedade Brasileira de Medicina Tropical 37: 354-356, 2004.

3. Buainain A, Giazzi JF. Determinação da Incidência de Enteroparasitas em Internados no Educandário “Domingos Sávio” de Araraquara. Revista de Farmácia e Odontologia 36:263-266, 1970.

4. Campos JADB, Farache Filho A, Faria, JB. Qualidade Sanitária da Água Distribuída para Consumo Humano pelo Sistema de Abastecimento Público da Cidade de Araraquara - SP. Alimentos e Nutrição 13: 117-129, 2002.

5. Castilho VLP, Uemura IH, Gonçalves EMN, Burattini MN. Incidência de Blastocystis bominis em amostras líquidas, semi-líquidas e pastosas de pacientes HIV+, internados no Hospital das Clínicas da FMUSP e no Hospital Emílio Ribas. In: Anais do $38^{\circ}$ Congresso Brasileiro de Patologia Clínica/Medicina Laboratorial, Florianópolis [CD-Room], 2004.

6. De Carli GA. Parasitologia Clínica: seleção de métodos e técnicas de laboratório para o diagnóstico das parasitoses humanas. Editora Atheneu, São Paulo, 2001.

7. Doyle PW, Helgason HH, Mathias RG, Proctor EM. Epidemiology and pathogenicity of Blastocystis hominis. Jounal of Clinical Microbiology 28: 116-121, 1990.

8. Giazzi JF, Fonseca LM, Moretti LA, Gomes ME. Prevalência de Enteroparasitas em habitantes da Vila Vieira da Cidade de Araraquara. Revista da Faculdade de Farmácia e Odontologia 8: 53-58, 1974.

9. Guimarães S, Sogayar MI. Blastocystis hominis: occurrence in children and staff members of municipal day-care centers from Botucatu, Sao Paulo State, Brazil. Memórias do Instituto Oswaldo Cruz 88: 427-429, 1993.

10. Kobayashi J, Hasegawa H, Forli AA, Nishimura NF, Yamanaka A, Shimabukuro T, Sato Y. Prevalence of intestinal parasitic infection in five farms in Holambra, São Paulo, Brazil. Revista do Instituto de Medicina Tropical de São Paulo 37: 13-18, 1995.
11. Ludwig KM, Frei F, Alvares Filho F, Paes TR. Correlação entre condições de saneamento básico e parasitoses intestinais na população de Assis, Estado de São Paulo. Revista da Sociedade Brasileira de Medicina Tropical 32: 547-555, 1999.

12. Martinez I, Belda Neto FM. Contribution to the Laboratory Diagnosis of Human Cryptosporidiosis. Revista do Instituto de Medicina Tropical de São Paulo 43: 79-82, 2001.

13. Martini AS, Giazzi JF, Belda Neto FM, Santos JL. Levantamento Coproparasitológico no Laboratório de Parasitologia da Faculdade de Farmácia e Odontologia de Araraquara. Revista da Faculdade de Farmácia e Odontologia 10: 247-251, 1976.

14. Miné JC, Fernandes MZT, Martinez I, Rosa JA. Prevalência de enteroparasitas na região de Araraquara - SP. In: Anais do $38^{\circ}$ Congresso Brasileiro de Patologia Clínica/Medicina Laboratorial, Florianópolis [CD-Room], 2004.

15. Moura H, Fernandez O, Viola JPB, Silva SP, Passos RH, Lima DB. Enteric parasites and HIV infection: Occurrence in AIDS patient in Rio de Janeiro, Brazil. Memórias do Instituto Oswaldo Cruz 84: 527-533, 1989.

16. Nascimento SA, Moitinho MLR. Blastocystis bominis and other intestinal parasites in a community of Pitanga city, Paraná State, Brazil. Revista do Instituto de Medicina Tropical de São Paulo 47: 213-217, 2005.

17. Pedrazzani ES, Mello DA, Pizzigat CP, Pripas S, Fucci M, Santoro MCM. Helmintoses Intestinais. III - Programa de Educação e Saúde em Verminoses. Revista de Saúde Pública 23: 189-195, 1989.

18. Pires ML, Dreyer G. Revendo a importância do Strongyloides stercoralis. Revista do Instituto de Medicina Tropical de São Paulo 48:175-182, 1993.

19. Rugai E, Mattos T, Brisola AP. Nova técnica para isolar larvas de nematoides de fezes - Modificação do método de Baermann. Revista do Instituto Adolfo Lutz 14: 5-8, 1954.

20. Schuster H, Chiodini PL. Parasitic infections of intestine. Current Opinion in Infectious Diseases 14: 587-591, 2001.

21. Senay H, Macpherson D. Blastocystis hominis with signs and symptoms of human disease. Journal of Clinical Microbiology 24: 548-550, 1990.

22. Stenzel DJ, Boreham PFL. Blastocystis hominis Revisited. Clinical Microbiology Reviews 9: 563-584, 1996.

23. Tan KSW. Blastocystis in human and animals: new using modern methodologies. Veterinary Parasitology 126: 121-144, 2004.

24. Teixeira ATLS. Garlipp CR, Bottini PV, Souza R. Blastocystis hominis: prevalência e patogenicidade. Revista Brasileira de Patologia Clínica 25: 7-9, 1989.

25. Wang KX, Li CP, Wang J, Cui YB. Epidemiological survey of Blastocystis hominis in Huainan City, Anhui Province, Chine. World Journal of Gastroenterology 8: 928-932, 2002.

26. Zierdt CH. Blastocystis hominis - Past and Future. Clinical Microbiology Reviews 4: 61-79, 1991. 